\title{
Different Levels of NGO Engagement and Reactions of the Government: Assessing the Sri Lankan Experience
}

\author{
Indi Ruwangi Akurugoda, $\mathrm{PhD}$ (Corresponding author) \\ Department of Public Policy, Faculty of Humanities and Social Sciences \\ University of Ruhuna, Matara 81000, Sri Lanka \\ Tel: 94-718-999-060 E-mail: indiakuru@gmail.com \\ Patrick Barrett, $\mathrm{PhD}$ (Co-author) \\ Department of Political Science and Public Policy, Faculty of Arts and Social Sciences \\ University of Waikato, Private Bag 3105, Hamilton 3240, New Zealand \\ E-mail: patrick.barrett@waikato.ac.nz \\ Alan Simpson, $\mathrm{PhD}$ (Co-author) \\ Department of Political Science and Public Policy, Faculty of Arts and Social Sciences \\ University of Waikato, Private Bag 3105, Hamilton 3240, New Zealand \\ E-mail: ac.simpson@xtra.co.nz
}

Received: April 30, 2017 Accepted: May 26, 2017 Published: June 30, 2017

doi:10.5296/jad.v3i2.11143 URL: https://doi.org/10.5296/jad.v3i2.11143

\begin{abstract}
Sri Lankan governments have a history of contradictory forms of engagement with NGOs and foreign donors, on the one hand embracing opportunities to work with and coordinate NGO donations for development, and on the other discouraging and rejecting more localised NGO activities. Successive governments have welcomed NGO and foreign donor funds for large scale construction projects. At the same time, with the support of Sinhala nationalist groups, governments have also portrayed NGOs and foreign donors as imperial agents. This criticism has been used against NGOs involved in the promotion and protection of human rights, especially in the war affected areas. This inconsistent behaviour of governments towards NGOs and foreign donors reflects opportunistic politics. Some NGOs and foreign donor agencies have successfully managed to navigate these contradictory government positions. Based on research in the southern and eastern provinces in Sri Lanka, this paper analyses effective NGO engagement at the local level during the post-tsunami and post-war situations. It focuses on those NGOs that have maintained government backing while also positively supporting local governance, community development and human rights.
\end{abstract}

Keywords: NGOs, foreign donors, local government, development, communities, nationalists, human rights, Sri Lanka 


\section{Introduction}

NGOs involved in humanitarian aid work in Sri Lanka have been criticised by Sinhala nationalists as representing the new face of imperialism, particularly NGOs involved in protecting human rights, and especially during the civil war. They have specifically been portrayed as "imperial" or "foreign" agents, and a threat to the sovereignty, territorial integrity and national security of the country (Uyangoda, 1995; Jayawardena, 1995). The remarkable $\mathrm{NGO}$ and foreign donor involvement in support of recovery projects after the tsunami of 2004 and at the end of the civil war in 2009, however, have marked the need to rethink the nature of NGO activities and foreign aid management and distribution. Through a case study of the contemporary Sri Lankan experience, this paper discusses the nationalist criticisms of NGOs and foreign donors. The paper analyses why recent governments, with the backing of Sinhala nationalist political parties and groups, support some NGOs and restrict the others. Based on research in the southern and eastern provinces of Sri Lanka, the paper then assesses the responses at the local level and identifies the activities of NGOs that contribute towards empowering local government and communities, and promoting inclusive local governance and development in Sri Lanka.

\section{Background}

Colonialism has had a lasting impact on the economic, political, social and cultural structures of many countries, and many former colonised countries have been left with complex arrangements, a hybrid of new colonial settings and old societal structures. Sri Lankan history of colonial rule for 443 years, first under the Portuguese, then the Dutch and later the British, contributed to the development of a culturally complex society, this arising from diverse ethnic, religious and caste systems. The introduction of colonial social and political structures only increased the complexities associated with governing. For example, when British colonial rulers promoted Western religions, a considerable number of Buddhist and Hindu adherents converted to Christianity, while those who remained as Buddhists imitated the new Protestant system of education, and new Buddhist schools were created to compete with Catholic schools. Within this context of increasing complexity, colonial administrative and governing structures were superimposed, undermining and transforming traditional Sri Lankan society.

Following independence in 1948, power shifted to post-colonial rulers who were faced with the need to address multiple problems, many of which had roots in the pre-colonial and colonial social, political and economic structures. An example is the British-based system of administration and government, including the British-influenced education system, which coexisted alongside traditional ethnic, religious, caste and social class hierarchies and the temple-based, ancient Buddhist education system (Piriven). The economy was designed around the production of exports to meet the needs of former colonial powers, but alongside this the pre-colonial, traditional agricultural system remained. While the indigenous cultures had been influenced by Western culture, those cultures have not been demonstrably altered. This political, economic, social and cultural complexity has presented significant challenges to post-independence rulers in Sri Lanka, one of which has been the emergence of a strong Tamil nationalist movement, leading to the civil war which lasted for nearly 30 years. Alongside this has been two youth insurrections that resulted in a large number of killings 
and disappearances. Against the background of colonialism, however, successive Sri Lankan governments have been suspicious of foreign influences in the governing of the nation, including international NGOs,

\section{Nationalist Critiques and NGOs: The Sri Lankan Experience}

\subsection{NGO Politics in Post-independence Sri Lanka}

Sri Lankan society has a long history of association with the organisational forms known today as NGOs. Prior to independency, Wew Sabhas (irrigation councils) (Note 1) and Christian missionary organisations were significant examples. From 1971 onwards, the involvement of NGOs within Sri Lankan society increased in response to the emergence of youth insurrections and ethnic conflict. NGO involvement brought new perspectives to these issues and contributed to a new awareness within Sri Lankan society of problematic social, political and economic issues (Kloos, 1999, p. 13). Subsequently, the open economic policy introduced in 1977 by the newly elected United National Party (UNP) opened spaces for NGOs to initiate social welfare activities where the state played a less active role or where it had completely ceased to act (Perera, 1998).

The 1980s and 1990s have been described as the era of "state failure," and with this came a huge expansion of the international NGO movement (Duffield, 2007). NGOs became extensively involved in worldwide humanitarian, peace enforcement and peace keeping operations. As a consequence, NGOs acquired a non-state or petty sovereign power to address the effects of continuing underdevelopment in former colonised countries, these being problems such as poverty, health crises, displacement, economic collapse, weak and ineffective government and social exclusion (Duffield, 2007).

In the 1980s, NGOs that worked in Sri Lanka expanded their concerns from development-oriented activities to the rights-oriented sphere. This emanated from the prolonged war between the Liberation Tigers of Tamil Eelam (LTTE) and the government forces, and the second youth insurrection of the Janatha Vimukthi Peramuna (JVP) which saw numerous human rights violations, and which resulted in Amnesty International and United Nations (UN)-based organisations becoming involved in activities associated with the protection of human rights and support for war-affected people through relief and rehabilitation work (Fernando, 2003). Later in the 1980s and in the 1990s, a number of NGOs actively campaigned for peace and for the democratic rights of the Tamil people. These included the Movement for Inter-Racial Justice and Equality (MIRJE), the Movement for the Defence of Democratic Rights (MDDR), Information Monitor on Human Rights (INFORM), Women for Peace, Dharmavedi Institute for Communication and Peace, National Christian Council, Citizens' Committee for National Harmony, and Sarvodaya (Uyangoda, 1995, p. 7). These were multi-ethnic advocacy and activist groups which shared a commitment and vision for progress in Sri Lanka, conceived on the basis of liberal and humanitarian concepts of ethnic harmony, justice, and equality (Uyangoda, 1995, p. 7).

The relationship between the Sri Lankan government and NGOs has changed over time in accordance with different government policies and subsequent challenges to the presence and activities of NGOs. In the 1994 Parliamentary election, the NGOs and People's Alliance (PA) government shared common ground on the need to solve the ethnic conflict through a 
negotiated political settlement (Fernando, 2003). NGOs became involved in two key initiatives of the PA government implementing programmes towards a non-military solution to the ethnic conflict to restore peace: the Sudu Nelum Viyaparaya (the white lotus movement) and the National Integration and Planning Unit (NIPU) (Fernando, 2003). But when the PA government failed in its peace negotiations with the LTTE and decided to go back to a military strategy, human rights-based NGOs began to revert to the watch-dog role they had played earlier as many incidents of human rights violations began to be reported, especially in war-affected areas (Fernando, 2003). Election malpractice, violence and the misuse of power by the government were also reported during the 1999 Wayamba (north western) provincial council election, where NGOs played an active role in monitoring the election process and where they openly confronted and criticised the government's actions (Fernando, 2003).

Earlier, in mid-November 1995, the official meetings of the Sri Lankan NGO Forum (Note 2) had been disturbed by rioters. In the same month, the Sri Lankan army launched operation Riviresa, which was meant to wrench Jaffna from the LTTE. Sinhala nationalist groups and a number of Sinhala newspapers created the impression that the forum was held in order to call for the end of the military campaign, arguing that NGOs supported the LTTE (Kloos, 1999, p. 35). Although there was no evidence to justify this suspicion against NGOs, the government did not take any action to reject it (Kloos, 1999, p. 36). The attacks by Sinhala nationalist groups on NGOs as foreign agents who supported the LTTE were countered by Perera (1995, p. 31) as follows: "It is quite absurd to believe that at a large meeting of around 80 NGOs, almost all of them local, that anything 'anti-Sri Lanka' could ever have been decided upon." Uyangoda (1995, p. 6) also commented:

Actually, this "foreign agent" argument is linked to an ideology of xenophobia, propagated by a section of Sri Lankans who, despite their own connections with foreign organisations, business enterprises and individuals, appear to believe that "foreign links" endanger national security.

It is significant that the foreign funding of NGO peace work had, at that time, come under harsh criticism in Sri Lanka. The most vociferous opposition to NGO promotion of peace processes came from Sinhala nationalist groups (Orjuela, 2005, p. 7), and it was militant Sinhala groups that vilified "foreign-funded NGOs" for undermining the morale of the troops and pursuing "selfish aims" instead of thinking of the "good of the nation" (Wickramasinghe, 2001, pp. 40-41). The government, together with such groups, had come out against the human rights-based NGOs on the argument that they endangered national security (Uyangoda, 1995, pp. 7-8). Situations of war tend to make people emotional and fearful, providing an occasion for nationalists to rise against "foreign conspiracies" and local "treason" (Jayawardena, 1995, p. 10). Uyangoda (1995, p. 8) criticised this position, claiming that: "It is sheer nonsense to suggest that these NGOs have been challenging the sovereignty of the Sri Lankan state." If one really wanted to demonise, terrorise and silence one's enemy, the easiest way was to suggest collusion with the LTTE (Uyangoda, 1995, p. 8) which at the time was fighting for a separate state within Sri Lanka.

Arguments suggesting NGO collusion with the LTTE asserted that NGOs had supported and funded the LTTE and, in the north, there had been pro-LTTE NGOs. Humanitarian NGOs 


\section{$\triangle$ Macrothink}

which had worked in the conflict areas were branded as pro-LTTE because they had worked among civilians in LTTE-controlled areas (Uyangoda, 1995, p. 8). Only a handful of international NGOs were working in the LTTE-controlled north where there was no legal recourse or protection apart from LTTE structures (Brabant, 1995, p. 15). For example, the International Committee of the Red Cross (ICRC) and the United Nations High Commissioner for Refugees (UNHCR) were there because in situations of armed conflicts, direct parties to the conflict are not always capable of looking after, and providing for, the civilian population, affected by the conflict itself (Uyangoda, 1995, p. 8). These NGOs provided assistance to displaced and resettled groups of people that led observers to wonder whether they were filling a gap or substituting for government (Brabant, 1995, p. 14). At the same time, the LTTE had a preference for keeping the international presence to the absolute minimum (Brabant, 1995, p. 15). The reality was that the critics knew that no international humanitarian NGO had worked in Sri Lanka's north without being invited by the government and asked by the government to carry out specific activities (Uyangoda, 1995, p. 8). Some critics have failed to understand that while it is possible to pressure a legitimate state which has signed binding treaties and conventions relating to humanitarian law, it is not feasible to exert similar pressure on rebel groups (Wickramasinghe, 2001, p. 152). Given this context, the suspicion that the NGOs had been in collusion with the LTTE is not supported by evidence.

\subsection{Post-tsunami and Post-war Situations}

The governments together with the support of Sinhala nationalist political parties and groups continued to criticise NGOs in the $21^{\text {st }}$ century. In 2004, the United People's Freedom Alliance (UPFA), an alliance of the Sri Lanka Freedom Party (SLFP) and the Sinhala nationalist JVP, came into power. Later this alliance received the support of the Jathika Hela Urumaya (JHU), another Sinhala nationalist political party and this collaboration again strengthened nationalist criticisms of NGOs. Political responses to NGOs in Sri Lanka during this period were heavily influenced by the tsunami of December 2004.

The unprecedented international response to the tsunami contributed towards what was an unorganised funding environment, which resulted in numerous examples of malpractice (Note 3) (Walton, 2008, p. 142).Walton (2008, p. 142) mentions that this response not only transformed the NGO sector in Sri Lanka by making it richer, it also boosted the public consciousness of NGOs. This international response in turn, increased the potential advantages open to political actors who criticised NGOs as a means of articulating their own political visions which, for nationalist groups, usually meant highlighting the corrupting influences of Western culture or political interference. As a result, well-established nationalist discourses about the harmful impact of NGOs on Sri Lankan life gained greater relevance and public perceptions of NGOs were damaged (Walton, 2008, p. 142).

However, the tsunami rapidly elevated the NGO sector from an insignificant concern for government, to one which was suddenly receiving and distributing foreign resources and social welfare on a scale comparable to that of the state (Walton, 2008, p. 142). Furthermore, the tsunami response exposed failures in government decision making and operational weakness in the aftermath of the tsunami (Walton, 2008, p. 142). The government's response was to grab the full control of aid management and distribution process and to direct NGOs 


\section{MInstitute ${ }^{\text {Macrothink }}$}

and foreign aid according to its agendas. This reflected the dual behaviour of government to attack NGOs by one side and to use their funds to fulfil government's agendas by other side.

The election of a new President in November 2005 began a period of even more intense hostility towards NGOs. According to Walton (2008, p. 142), this prompted a sudden widening of the ideological gap between the government and the majority of donors and NGOs working on peace building whose ideas had fitted closely with the previous United National Front (UNF) government's (Note 4) version of liberal peace building. This shift was accelerated by the government's reliance on two Sinhala nationalist parties, the JVP and the JHU, as partners in the ruling UPFA coalition. Their new prominence allowed them much greater space to promote their views through the mainstream state media, and to encourage government measures to restrict the work of NGOs (Walton, 2008, p. 142).

Walton (2008, p. 142) further notes that the backlash against NGOs was also closely linked to the slide back to full-scale military confrontation, which began in 2006. The government's increasingly militarist approach reduced the space for the critical voices that had grown in confidence during the ceasefire period from 2002 to 2004 (Walton, 2008, p. 142). By putting the country on a war footing, the government was also able to tighten its grip over the media and use it to attack human rights and peace advocates, who were increasingly seen as a threat to the state's military objectives (Walton, 2008, p. 142), and indicated a return to past beliefs about NGOs.

In January 2006, a Parliamentary select committee into the activities and impact of NGOs was launched with a "special focus" on post-tsunami developments. Its terms of reference clearly reflected concerns linked to the ethnic conflict, including the allegations that some NGOs were engaged in activities that were "inimical to the sovereignty and integrity of Sri Lanka," "detrimental to the national and social wellbeing of the country" and adversely affected "national security" (Walton, 2008, p. 143). Some authors, such as Walton (2008), therefore argue that NGO legitimacy in Sri Lanka was reliant on a number of factors specific to the Sri Lankan context, such as a highly centralised political system, a lack of legal protection for NGOs, and a sense that NGOs were elitist and threatened the aims of a nationalist political agenda. The legal procedures were not meant to evaluate the utility of NGO activities and projects but to monitor them, which left them subject to control through state intervention (Perera, 1998). Such legal procedures reflected the government's aims to suppress and control NGOs.

When the war ended in 2009, the government at that time was unable to put forward arguments of national security anymore. In the post-war period, numerous human rights violations occurred in Sri Lanka. The government's response to these issues was manifest with the government fearing NGOs might spread news of these violent incidents to the outside world. Thus, the government tried to suppress the NGOs by controlling them under the auspices of the Defence Ministry. According to a special gazette notice issued by the President on April 30, 2010, the NGO Secretariat (Note 5) functioned under the purview of the Ministry of Defence till January 2015. (Note 6) While the aims of establishing the NGO Secretariat may be clear and reasonable, the problem was the control held by the Defence Ministry. According to critics, NGOs are required to submit financial statements, audited reports and work plans on a regular basis to the NGO Secretariat. Oversight of a clearly 
civilian function by the Ministry of Defence was deeply repressive and highly political. This was apparent in the restrictions that had been placed on organisations limiting work to specific activities and subject areas. For example, after the war the Sri Lankan military forces denied the NGOs all access to the IDP camps. (Note 7) The monitoring of such organisations, mainly working to address human rights and humanitarian concerns, especially in the north and the east, created an environment of self-censorship and curtailed meaningful intervention (Sumanthiran, 2011).

During the UPFA government rule, NGOs faced continuous limitations in terms of their operational capacities. For example, the NGO registration process of the NGO Secretariat consisted of vague and complex regulations designed to discourage NGOs. This created a path for the misuse of laws and the NGO Secretariat to direct NGOs towards the fulfilment of government's political agendas.

It is clear from the above discussion that the nationalist critiques on NGOs have two facets. First, when NGOs investigate and question human rights violations by the government, with the support of nationalist political parties and groups, the government portrays NGOs as a threat to national security, sovereignty and territorial integrity of the country. Second, when NGOs reject working according to government's political agendas using the same nationalist elements, government tries to suppress NGOs and their activities. However, the interesting point here is that the behaviour of government over NGOs differs according to their activities. Government does not reject all NGOs on a similar basis. The nationalist criticisms emerge only when NGOs act against the government's desires. Government wants NGO funds but only when NGOs agree with government's political agendas. Government rejects humanitarian NGOs because when they reveal human rights violations of the country, the position of government in the international arena collapses. It is, therefore, clear that the government-sponsored nationalist critiques on NGOs are politically opportunistic and far beyond the truth.

\section{Research Methods}

Given its long colonial history and highly centralised government operating with the support of Sinhala nationalist parties and groups that work against decentralisation, the Sri Lankan experience provides a basis for examining the ways in which NGOs and foreign donors involve in development and governance. The flow of large amounts of foreign aid and NGO support in the post-tsunami and post-war periods, and the reaction to that by successive governments, provide an opportunity to examine different responses of various NGO and donor activities.

In addition to a comprehensive review of NGO literature in the Sri Lankan context, this research involved field work in the southern and eastern provinces, and the examination of NGO involvement with on 12 local government bodies including municipal councils, urban councils and Pradeshiya Sabhas. Interviews were carried out with 47 respondents including national, provincial and local government representatives, and NGO officials, exploring views regarding the role of foreign funds and NGOs in local development and governance.

The southern and eastern provinces were severely affected by the tsunami in 2004 and the eastern province was also affected by the civil war which ended only in 2009. The tsunami 
and the war resulted in large amounts of foreign funds and NGO support flowing into these provinces to promote recovery and reconstruction. In-depth interviews were carried out with two political representatives from each local government body, those representing the governing party and the opposition party. (Note 8) The administrative officials were selected from district and divisional secretariats situated in the selected local government areas. The officer contacted was either the NGO coordinating officer of the district secretariat or the assistant director-planning of the divisional secretariat. Provincial and national level administrative officials were selected through snowball sampling. (Note 9) When selecting the NGOs, the main concern was to determine the different types of NGO contributions in local development and governance, and only NGOs that had been involved in recently completed and ongoing projects in the south and east areas were selected. All of the selected NGOs were foreign-funded, mainly from American (United States of America), Australian, Canadian and European sources.

The research followed the established principles of human research ethics approved by the Faculty of Arts and Social Sciences, University of Waikato, New Zealand. The research was carried in two phases: first from May to September 2011 and second from June to September 2012. (Note 10) The collected data was organised manually into categories on the basis of themes, concepts, or similar features. Analysis went beyond description to interpreting what had been said in terms of the research questions and existing literature (Smith \& Davies, 2010, $\mathrm{p}, 155)$.

\section{Effective NGO Engagement at the Local Level}

The tsunami led to major damage in 70 of 311 local government areas in seven municipal council areas, 14 urban council areas and 49 Pradeshiya Sabha areas in Sri Lanka. Damage was estimated at Rs.2833 million, which is approximately US\$30 million (Ministry of Provincial Councils, 2007, p. 12). It led to the destruction of many local government buildings and paralysed local government service deliveries. Roads and bridges were destroyed, public markets and shopping complexes were ruined and there was a loss of income from taxes and rates which left local government bodies in a most difficult fiscal situation (Ministry of Provincial Councils, 2007, p. 12). In this context, the perceived inadequacies of local government in Sri Lanka were highlighted. As stressed by many respondents, local government in Sri Lanka lacks the capabilities and capacities such as power, legal knowledge, funds, resources and technologies to address local development.

In contrast to from nationalist critiques and the position adopted by the government towards NGOs, interviews with local political representatives and administrative officials maintained that foreign donor aid and NGO assistance had made a significant contribution in overcoming problems of local development and governance. This research reveals NGO activities that contribute to addressing such problems.

There are many international NGOs and foreign donors directly involved in different projects at the local level. Some of them have country offices, and some of them have area offices located in local government areas to carry-on their projects at the local level. Some of them work together with local NGOs. While some of them are directly involved in project activities at the local level, others provide aid and guidance to local NGOs. Many NGOs directly connect with central government-controlled administrative authorities such as district 
and divisional secretariats. Some NGOs directly connect with local government and assist local government representatives and staff through providing knowledge and encouraging people's participation at the local level towards effective policy processes and local development. The following discussion, thus, outlines effective NGO engagement at the local level in Sri Lanka.

\subsection{Seeking Local Input into the Design of Development Projects}

The interviews with local government and NGO officials revealed the concern that central government was neglecting the development needs of local communities in favour of large scale infrastructure development projects. Examples of this included the use of foreign aid funds to build a harbour, an airport, an international cricket stadium and an international conference centre in the Hambantota district in the southern province. This district was located in the dry zone and experienced a serious water shortage problem and a lack of basic facilities such as public health infrastructure and sanitation. In this context, the large, centrally directed projects were seen as being poorly designed and unsuitable for addressing the actual development needs in the area. A feature of the post-civil war environment in the eastern province has been the large role played by the armed forces in the centrally-led post-war development. Here, the respondents reported that many traditional agricultural lands and fishing areas that have been the mainstay of local people have been confiscated by the military, again for the purpose of conducting large scale construction projects and, as a result, local communities have lost their primary source of sustenance.

In this context, a number of NGOs and foreign donor agencies have responded by connecting directly with local governments and communities in seeking solutions to problems. An example is the tsunami reconstruction and rehabilitation programme of the Canadian International Development Agency (CIDA) and the Federation of Canadian Municipalities (FCM) which has worked closely with local government elected representatives (ACDI CIDA, n.d.). What was distinctive about this work was the way FCM local agents work with local government representatives in the design of rural infrastructure projects. These included rebuilding of local roads and drainage systems. The projects were a partnership, with local communities able to influence the order of priorities for rural infrastructure by submitting proposals and contributing 50 per cent of the project costs in the form of labour. FCM provided relevant assistance, especially in the rehabilitation of the service delivery systems in tsunami-affected local government bodies in the southern and eastern provinces (Ministry of Local Government, 2009, p. 18). FCM's participatory mechanisms, like the community support fund (CSF), (Note 11) and mid-term planning systems and procedures (ACDI - CIDA, n.d.), were described as having significantly positive results.

Another instance of a significant local government and community collaboration was the WASSER project conducted under a partnership between a Sri Lankan local government and the city of Munich, Germany. In this project, assistance was offered to the tsunami-affected cities of Batticaloa and Kalmunai. (Note 12) The project objectives included planning and setting-up of sewerage systems and the provision of drinking water supplies for the poorest communities. As a result of the collaboration, local government capabilities were described as having been significantly enhanced in the fields of environmental planning, environmental management and disaster mitigation (Kalmunai Municipal Council, 2010). The WASSER 
project was a remarkable success in educating the local community about conserving water, and assisting poor families in meeting their drinking water problems.

The tsunami severely damaged houses and belongings increasing the amount of solid waste which put pressure on the collection infrastructure, requiring NGOs to focus on solid waste management (VNG International, 2006). The government has not been concerned about waste management in local areas and there has not been a national policy to do so, but there has been remarkable support from several NGOs and foreign donors for waste management projects in many local government areas. The solid waste management project of the Matara municipal council is an example. It is funded by the European Union (EU), the Japan International Cooperation Agency (JICA) provided the relevant technology and training, and the waste management project itself has been controlled by the Matara municipal council which benefits directly by getting all the profits. (Note 13) A further example of NGOs successfully becoming involved in waste management projects includes Caritas Social and Economic Development (SED) in the Galle municipal council. It constructed buildings and donated machinery to establish a compost plant which is now handled by the municipal council although the project from time to time receives foreign funds from various sources for its maintenance. (Note 14) The EU was involved in a three-year waste management project called COWAM (Construction Waste Management) which built waste management infrastructure in Galle city. Through this project, staff members of the municipal council were trained in Germany and later the total ownership of the project was handed over to the Galle municipal council. The council now has the capacity to produce bricks and concrete chips which can be used for building and road construction. (Note 15) What is distinctive about all of these waste management infrastructure development projects is that they were designed in a way that took the specific needs of local government areas into account.

\subsection{Encouraging People's Participation in Local Policy Development}

Development initiatives are of little benefit if they do not connect with the people (ACDI CIDA, n.d.). Local government is the level of democracy at which the citizen has the most effective opportunity to participate actively and directly in local decisions (Sisk, 2001, p. 1). However, most local government bodies in Sri Lanka do not have effective links with their communities. Respondent local government representatives noted the difficulties of achieving people's participation in local development policy planning, and this did affect the ability to understand and address prominent local development needs. Some of the NGOs and donor agencies in this research were found to be actively involved in obtaining people's participation in local policy development processes.

The United States Agency for International Development (USAID)-funded Transparent Accountable Local Governance (TALG) programme is one such example. It was designed to help local government bodies make key political institutions more responsive to citizen input and improve service delivery, post-tsunami emergency recovery assistance, and the rule of law to protect and empower vulnerable groups (Asia Foundation, 2010). Through this, the Asia Foundation was supported to provide technical assistance and training to local government staff about the ways to encourage and obtain people's participation in development policy planning. This has been implemented in 35 local government areas across the country affected by the tsunami and/or by the war (Ministry of Local Government, 
2009, p. 17). A specific example of these positive outcomes is the Weligama urban council that, with the Asia Foundation assistance, engaged in a participatory process that specifically targeted local government staff and local communities, resulting in a four year plan and 16 development projects, (Note 16) with the council taking responsibility to implement them all. (Note 17) Supporting Regional Governance (SuRG), one of USAID's democracy and governance programmes, assists local government to build participatory governance forums and engage directly at the local level by encouraging citizens to participate in local government policy processes. This programme supports local government in particular areas, especially in the eastern province, to strengthen their capacity in planning, budgeting and in ensuring transparent and participatory planning processes. It centred on increasing citizen engagement in local government, strengthening inter-community reconciliation procedures and promoting social equity. (Note 18)

These examples illustrate that NGOs and foreign donor agencies have been instrumental in building two way communications between people and local government, enabling political representatives to get to know the people's problems and needs. (Note 19)

\subsection{Building Capacity of Elected and Appointed Local Government Officials}

The research findings indicate for effective NGO engagement in local development there should be a commitment to build the capacity of Sri Lankan communities to self-govern, and this included the provision of education and training to local government representatives and staff. Local government respondents highlighted the value of NGO assistance that led to the acquisition of usable knowledge and technological skills. It became apparent that most local government representatives lacked knowledge about their powers and income sources, and, therefore, were unable to act effectively in local development and governance. Some NGO programmes are designed to address this lack and, importantly, this type of assistance was welcomed by respondent local government officials.

SuRG was one such example, and it had identified a range of training needs for local government, including participatory planning, governance, proposal development, project management, office management, accounting, finance, leadership and legislature programmes. According to its programme manager, the core purpose of SuRG was to improve the knowledge and skills of elected representatives and staff to fulfil their core functions, increase public participation in decision making, increase transparency and accountability of local government functions, and enhance the public sector environment. It had provided technical assistance to many local government bodies in the eastern province through workshops, mentoring, technical assistance and focused training.

By building a relationship with local government, Transparency International's way of working also exemplified NGO activities that involved the provision of knowledge to local government representatives about income sources and ways of improving services. (Note 20) A consultant of the Transparency International stated that their programme of assistance was specifically focused on the making of strategic plans, especially four-year plans, and providing knowledge to Pradeshiya Sabhas about how to obtain funds.

Centre for Policy Alternatives (CPA) guides local government officials on effective methods of tax collection and provides knowledge to the people on taxes. The contact person of CPA's 
Governance and Anti-Corruption Programme commented that this helps improving income generation of local government bodies.

\subsection{Locally Targeted Poverty Alleviation and Economic Development Initiatives}

Poverty is a major problem among local communities in Sri Lanka. Although there are government-sponsored poverty alleviation programmes that cover the whole country under one common policy, these do not address the specific needs of the local poor. Local people have been continuously losing their sources of income, mostly due to centrally-led large scale construction projects and military involvement in development projects and local businesses. The result has been to maintain and reinforce the cycle of poverty (Sumanthiran, 2011). To address this matter, some NGOs are involved in locally targeted poverty alleviation projects.

To improve local people's social and economic status by focusing on women, youth, and what are referred to as the POP (poorest of the poor - the lowest economic level of the society), the Cooperative for Assistance and Relief Everywhere (CARE) International operates small scale projects in villages. CARE sees that the POP have no opportunities to enter development processes, and earn small wages on a daily basis. They are vulnerable and marginalised. (Note 21) To support rural communities to improve their living conditions, from its area office in the Hambantota district, CARE addresses rural development through a community participatory approach using the theory and practices of community governance based in the villages where the issues are livelihood development, environmental management, social resources, and infrastructure development. For example, if there is a person who knows carpentry, but does not own any equipment to carry on as a carpenter, CARE provides equipment and observes employment progress towards addressing future problems. These projects, therefore, address the specific needs of the poor. According to a team leader of the CARE, by establishing village operating units (VOUs) and selecting officials to represent the villagers, they support women and youth participation to alleviate poverty. The importance of these projects is that it ensures closer scrutiny of the poor local communities in the villages.

The Asia Foundation's Local Economic Governance (LEG) project is designed to promote local economic development in Sri Lanka. The Asia Foundation works with the private sector and local government bodies to facilitate private-public dialogues that provide a forum for local government and business leaders to discuss the impediments to economic growth in their localities and provinces (Asia Foundation, 2008). This provides opportunities to local communities to improve their local businesses and to find markets for their crops.

When assessing these projects in terms of the conditions for positive NGO and foreign donor involvement at the local government level, and in analysing whether the form of engagement meets local development needs, many advantages can be identified. Adding local input into local development project planning, encouraging people's participation in local government policy processes, educating local government representatives on their powers, functions and income sources, training local government staff to improve their management skills, and addressing the specific needs of the poor local communities have received critically important contributions. These indicate the varied benefits of NGOs and foreign donors in the selected local government areas, and signify the importance and potential of NGOs which contribute to governance and development. 


\section{Conclusion}

The complex history of colonial rule and of ethno-cultural diversities has contributed to many politico-economic and socio-cultural differences in Sri Lanka. Since decolonisation, Sri Lanka has been faced with internal problems of ethnic conflict, youth insurrections, human rights violations, poverty, election malpractices, violence and corruption. These failures of post-independence rulers reflect national politics and the lack of government commitment to address the various needs of the people and support local development.

Successive governments backed by Sinhala nationalist parties and groups have shown a tendency to concentrate the power of the central government at the expense of governing institutions at the local level. The sensitivity of the Sri Lankan society towards nationalism has made it easier to justify such initiatives by reference to the threat of outside enemies. NGOs have thus been labelled as imperial agents by such Sinhala nationalist parties and groups, and they have been portrayed as supportive of the Tamil nationalist groups and, therefore, a threat to the country's sovereignty, territorial integrity and national security. This criticism has been used mostly by governments as a means of preventing rights-oriented NGOs which have engaged in protecting the interests of the people, especially those affected by the war.

NGO involvement has been met with a number of attempts by government to restrict and discourage their activities and tarnish their image among the people. This anti-NGO trend has been government-sponsored but publicised by Sinhala nationalists. In Sri Lanka, the criticisms against NGOs and foreign donor agencies emerged because the governments wanted to prevent active NGO involvement towards protecting rights of the people. When NGOs are involved in protecting victimised and marginalised people, NGOs are seen as a threat, as a means of covering a government's own failures. However, government wanted to obtain NGO and donor funds towards fulfilling its own political agendas. For this purpose government tried to administer the whole aid management and distribution process.

During the post-tsunami and post-war situations, against a background that many local government properties were destroyed, and the central government was using foreign aid and directing NGOs to conduct large scale construction projects neglecting local development needs, the inadequacies of local government in Sri Lanka were demystified. This opened a path for some NGOs to realise the need of changing their way of involvement in local governance and development. The effective NGO engagement at the local level has resulted in many of the community development needs and the empowerment of local government being addressed. This research reveals the key role of NGOs and foreign donors at the local government level in seeking local input into rural infrastructure development and waste management, providing knowledge and training to local government political representatives and administrative officials, encouraging people's participation in local development planning and budgeting, and alleviating poverty of local communities. These indicate that NGOs have been involved in addressing local development problems which are neglected by the central government.

It is, therefore, evident that the central government's position on NGOs and foreign donors differs according to its opportunistic political aims. When humanitarian NGOs have come forward with human rights violation issues that government is responsible for, government 
brings various criticisms to restrict and reject NGO activities. But when NGOs and foreign donors come with large amounts of funds, the government welcomes them and attempts to handle such funds to fulfil its political agendas. The realisation of this dual behaviour of government has made some NGOs and foreign donors to connect directly with the local level to promote governance and development addressing local community needs. This trend has been highlighted during post-tsunami and post-war situations in Sri Lanka and can be identified making positive influences in the society and therefore needed to encourage.

\section{Acknowledgement}

This paper is the outcome of a post-doctoral stipendiary writing scholarship awarded to the corresponding author by the Faculty of Arts and Social Sciences, University of Waikato, New Zealand. Thanks to the University of Waikato for financial support and encouragement around academic publication. The authors gratefully acknowledge all participants involved in this research and appreciate the sharing of ideas and information. Special thanks to the staff of the Sri Lanka Parliament library and Social Scientists' Association (SSA) for their assistance of this research.

\section{References}

ACDI - CIDA. (n.d.). Tsunami reconstruction and rehabilitation programme. $A C D I-C I D A$. Retrieved from http:/www.acdi-cida.gc.ca/acdi-cida/ACDI-CIDA.nsf/eng/NAT215111822-M5J

Akurugoda, I.R. (2014). The politics of local government and development in Sri Lanka: An analysis of the contribution of non-governmental organisations (NGOs). (Doctoral thesis, University of Waikato, Hamilton, New Zealand). Retrieved from http://hdl.handle.net/10289/8930

Amnesty International. (2009). Sri Lanka: Unlock the camps in Sri Lanka: Safety and dignity for the displaced now. Amnesty International. Retrieved from http://www.amnesty.org/en/library/asset/ASA37/016/2009/en/5de112c8-c8d4-4c31-8144-2a6 9aa9fff58/asa370162009en.html

Asia Foundation. (2008). Policy advocacy handbook. Asia Foundation. Retrieved from http://www.localgovernance.lk

Asia Foundation. (2010). Country overview: Sri Lanka. Asia Foundation. Retrieved from http://asiafoundation.org/country/overview/sri-lanka

Brabant, K. (1995). NGO legislation: The Sri Lanka case. RPN, 19, 15.

Bryman, A. (2012). Social research methods. Oxford University Press.

Duffield, M. (2007). Development, territories, and people: Consolidating the external sovereign frontier. Alternatives: Global, Local, Political, 32, 235-240. https://doi.org/10.1177/030437540703200204

Fernando, U. (2003). The landscape of NGOs in Sri Lanka: Issues and challenges. Retrieved from http://www2.fmg.uva.nl/agids/publications/2003/fernando_ls.html 
Jayawardena, K. (1995). The NGO bogey. Pravada, 4(5 \& 6), 10-11.

Kalmunai Municipal Council. (2010). Completed projects: Kalmunai municipal council. Kalmunai Municipal Council. $\quad$ Retrieved from http://www.kalmunaimc.org/ProjectsCompleted.html

Kloos, P. (1999). The Sri Lankan government and the NGO's: An ambivalent relationship. Amsterdam: Vrije Universiteit.

Lanka Standard. (2005). Helping Hambantota investigation. Lanka Standard. Retrieved from http://www.lankastandard.com/vault/helping-hambantota-investigation/

Ministry of Local Government and Provincial Councils. (2009). Performance-2007 \& future plans-2008. Colombo: Ministry of Local Government and Provincial Councils.

Ministry of Provincial Councils and Local Government. (2007). Performance-2005 \& future plans-2006. Colombo: Ministry of Provincial Councils and Local Government.

Orjuela, C. (2005). Dilemmas of civil society aid: Donors, NGOs and the quest for peace in Sri Lanka. Peace and Democracy in South Asia, 1(1), 1-12.

Perera, J. (1995). Today the NGOs; tomorrow... Pravada, 4(4), 31.

Perera, S. (1998). Non-government organizations in Sri Lanka: The dynamics, the impact, the rhetoric and the politics. Retrieved from http://sasankaperera.com/wp-content/uploads/2011/04/NGOs-1998.pdf

Sisk, T. D. (2001). Introduction. In T. D. Sisk (Ed), Democracy at the local level: The international IDEA handbook on participation, representation, conflict management, and governance (pp. 1-8). Stockholm: IDEA.

Smith, K. \& Davies, J. (2010). Qualitative data analysis. In L. Dahlberg, \& C. McCaig (Eds), Practical research and evaluation: A start-to-finish guide for practitioners (pp. 145-158). London: SAGE. https://doi.org/10.4135/9781446268346.n10

Sri Lanka State Terrorism. (2009). Sri Lanka's tsunami aid: Over \$1 billion missing or misappropriated. Sri Lanka State Terrorism. Retrieved from http://srilankastateterrorism.blogspot.com/2009/12/sri-lankas-tsunami-aid-over-1-billion.html

Sumanthiran, M. A. (October 21, 2011). Situation in north-eastern Sri Lanka: A series of serious concerns. A report tabled in Parliament of Sri Lanka. Retrieved from www.dbsjeyaraj.com

Swanborn, P. G. (2010). Case study research: What, why and how?. London: SAGE.

Uyangoda, J. (1995). NGOs, hate politics and questions of democracy. Pravada, 4(5 \& 6), 6-9.

VNG International. (2006). LOGO south country programme for Sri Lanka/solid waste management of local government bodies in Sri Lanka. VNG International. Retrieved from http://www.cities-localgovernments.org/committees/cib/Upload/compendium/EN_38_LOGO 
_South_Country_Programme_Sri_Lanka.pdf

Walton, O. (2008). Conflict, peacebuilding and NGO legitimacy: National NGOs in Sri $\begin{array}{llll}\text { Lanka. Conflict, } \quad \text { Security } \quad \& \quad \text { Development, } & 8(1), \quad 133-167 .\end{array}$ https://doi.org/10.1080/14678800801977146

Wickramasinghe, N. (2001). Civil society in Sri Lanka: New circles of power. New Delhi: SAGE.

\section{Notes}

Note 1. Wev Sabhas maintained and managed small scale water reservoirs for agricultural needs.

Note 2. The establishment of an NGO Forum in 1993 followed the 1990 creation of the European NGO Forum on Sri Lanka. The Forum was established to address the problems which emerged in 1987 after the arrival in Sri Lanka of the Indian Peace Keeping Force (IPKF). The Forum sought attention from the international community for the increasing violation of human rights. A number of European NGOs participated in the Forum, however, providing information on Sri Lanka was one goal; exerting pressure on the combatants in Sri Lanka another. The meetings of the Sri Lankan Forum were presided over by the chairman of the European Forum and the chairman of the Sri Lankan Forum. Sri Lankans decided in 1994 to form a "counter Forum" allowing four types of NGOs to participate: those in the fields of human rights, relief and rehabilitation, economic development, and peace (Kloos, 1999, pp. 33-35). The topics to be discussed were economic development, human rights and NGO partnership in addition to the more sensitive topics of peace and humanitarian assistance (Perera, 1995, p. 31).

Note 3. The tsunami funds scandal popularly known as the Helping Hambantota case is the most prominent fraudulent case of tsunami funds by government (See Lanka Standard, 2005). Moreover, nearly half a billion US dollars in tsunami aid for Sri Lanka is unaccounted for and over US\$600 million has been spent on projects unrelated to the disaster (See Sri Lanka State Terrorism, 2009).

Note 4. The UNF coalition, led by UNP leader Ranil Wickremasinghe, won the 2001 Parliamentary elections. The UNF government lasted till April 2004.

Note 5. The NGO Secretariat was established in 1996 to deal with several matters related to local and foreign NGOs operating in Sri Lanka. The goals of the Secretariat are to ensure the registration of all NGOs which function in Sri Lanka, and to assess if they are functioning within the frame of government policies.

Note 6. A new government has been established in January 2015 and at the present the NGO Secretariat functions under the Ministry of National Dialogue.

Note 7. This was later relaxed after pressure was exerted by the international community (See Amnesty International, 2009). 


\section{Macrothink}

Note 8 . Where there was a second opposition party, this representative was also interviewed.

Note 9. See Bryman, 2012, p. 424, on snowball sampling. Also Swanborn, 2010, p. 74.

Note 10. For more details on methodology see Akurugoda, 2014, pp.37-54.

Note 11. The CSF has been used mostly for road construction. Without contractors, road building became cheaper, local ownership and maintenance better, real estate values improved and, with it, an improved tax base for local government. The CSF model provoked a re-consideration of policies with respect to the size of road eligible for municipal attention (See ACDI - CIDA, n.d.).

Note 12. Kalmunai experienced the highest death toll and property damage in Sri Lanka (Kalmunai Municipal Council, 2010).

Note 13. Respondent PHI Officer of the Matara municipal council.

Note 14. Respondent Technical Officer of the Galle municipal council.

Note 15. Information provided by the Galle municipal council.

Note 16. Some of the projects are: construction of two public fairs, an urban council building, meeting halls for fishermen, a library, children's parks, parking place for three wheelers, solid waste management, a compost yard development and the purchase of tractors.

Note 17. Respondent Community Development Officer of the Weligama urban council.

Note 18. Respondent Programme Manager of the SuRG of USAID.

Note 19. Respondent Contact Person of the Governance and Anti-Corruption Programme, CPA.

Note 20. Respondent Consultant of the Transparency International - Sri Lanka.

Note 21. Respondent Team Leader of the CARE International - Hambantota Office.

\section{Copyright Disclaimer}

Copyright for this article is retained by the author(s), with first publication rights granted to the journal.

This is an open-access article distributed under the terms and conditions of the Creative Commons Attribution license (http://creativecommons.org/licenses/by/4.0/). 